\title{
Development of Visual Media Characteristic of Batak Culture "Dalihan Na Tolu" for Students in 6th Grade Elementary School
}

\author{
Defa $^{1}$, Wisman Hadi ${ }^{2}$, Daulat Saragi ${ }^{3}$ \\ 1,3Department of Elementary School, Universitas Negeri Medan, Indonesia \\ ${ }^{2}$ Department of Indonesian Language Education, Universitas Negeri Medan, Indonesia \\ Email: devanyaulyta@gmail.com
}

\begin{abstract}
The research is using the $4 \mathrm{D}$ Thiagarajan development model consisting of Define, Design, Development and Dissemination. The validation results of three experts consisting of material experts, design experts and media experts with a very decent category. Once validated by the three experts, the media tested on two groups of small groups and big groups by demonstrating the effectiveness of the media. One of the patterns of kinship adopted from the value of Batak culture contains many positive and good elements that can be used as a role model in the use of technology. Making the use of technology is growing by having a cultural corridor that can align in its development and use in both the digital world though. In this study gave birth to a visual learning media that collaborated with the values of Batak culture. Keywords: visual learning media; Indonesian language; Batak culture " Dalihan Na Tolu"
\end{abstract}

\section{Introduction}

The development of Science and Technology in this globalization era can be a problem, where each individual has its own way in the face of technological advances. The problem is the gap between technological developments and cultural values. The use of false technologies may violate existing cultural norms or rules. The life of Batak people is unique in the culture of one of them is in the pattern of kinship "Dalihan $\mathrm{Na}$ Tolu". Indonesia is a country that has many tribes and has much cultural diversity. Culture is something that does not bid to be left alone when the development of science and technology develops. The role of a positive culture is as a barrier to each individual to implement the prevailing norms in the community. The role of culture is very important for human life with the rules. Therefore the necessity of a means whereby cultural values are attributed in life to the presence of IPTEK still contains cultural values. One of them is making learning media that has a characteristic of local culture.

Media is an intermediary for good and joyful communication between teachers and students. Students' learning spirit will increase when teachers are able to give something different through interesting learning media in the learning process. Certainly the role of learning media as a tool used to distribute messages from teachers to students in order to stimulate the students ' thoughts, feelings, attentiveness and interests in the optimal learning process. Therefore, it takes learning medium that is used as a means to facilitate teachers to convey the material in learning so that students are not bored and the purpose of learning is achieved. Based on Syakur (2020) online media or also called E-learning which is popular nowadays is distance learning that can be accessed in various ways. Students do not have to be in the same room as education in the past. The development of technology, communication and information, especially the internet has become a demand for teachers in Indonesia to be able to use it as a source of positive learning media in supporting teaching and learning processes (Prasasti, 2019). 


\section{Britain International of Humanities and Social Sciences (BIoHS) Journal \\ ISSN: 2685-3868(Online), 2685-1989(Print) \\ Vol. 2, No. 3, October 2020, Page: 757-764}

\section{Review of Literatures}

According Hadi (2018), The media still has the same purpose but user adds interaction and brings interesting features for the easy of use of the media system. Saragi (2018), the use of learning media in learning can generate interest, motivation, help students improve understanding, present data with interesting and reliable, facilitate interpretation of data, and compress information. Learning Media is important during the learning process for teachers to avoid from learning objectives and for students can easily understand the material presented with the help of learning media. Interesting learning Media will create an active and varied learning process to improve the quality of learning. But in selecting learning media, teachers should know some criteria when choosing the appropriate media for the students. It is like that of Sadiman (2009:85) that the criteria of media selection must be developed in accordance with the objectives, conditions, and limitations that exist by remembering the ability and characteristic characteristics of the media that Concerned. The media tools needed are media capable of assisting the teacher in presenting the material, as well as being able to see the process such as actual events and maximised sense of power that the students have and can minimize the limitations Students have the material information to be absorbed properly. Good learning Media is a medium that matches the characteristics, needs and the usefulness of more while in the process of learning activities for both students and Gurui. New media in question is the development of communication technology that in history has expanded the reach of human communication. Thesedevelopments culminated in the era of modern mass media Syakur (2020).

Visual Learning Media is one of the development of the culturally-characterized science, where the media of visual learning is made by having the values of Batak culture. Combining science and technology and cultural values makes this me dia must be developed to be seen how the impact in the learning process is included in the students. The effort to develop the values of Batak culture that contained in the pattern of kinship "Dalihan Na Tolu" in line with the rapid development of science and technology is expected to give color in learning and the expected occurrence of changes in Education in Indonesia.

\section{Methods}

In this paper, this is a visual learning media with Batak culture "Dalihan Na Tolu" which directs the method of media use in learning to help students. Learning-oriented Theme Material 7 Leadership subtheme 2 leaders around me. In this theme consists of several subjects, but limited use of media learning only on the content of Indonesian language that is in the speech material. This material is one of the most boring material, because the teacher is too many lectures. Lack of students' interest in learning materials is the cause of one of the students ' learning outcomes to decline, especially in this material contains elements of Batak culture values. Teachers lack the idea to make learning improvements in processing interesting learning on this material, because it is very rare in the content of Indonesian language lessons have a learning media that suits the needs of students and materials Learning. Moreover, in this material has cultural features, of course it becomes a problem in learning.

In the use of a visual learning media with Batak culture "Dalihan Na Tolu", it will be seen to use the media how the cultural characteristics of Batak cultural kinship patterns play a role in learning. The use of this media can be used in groups or individuals, where in the media there are measures of media use of the material. Making it easier for students to do the learning process. As for its use in the learning process as follows: 


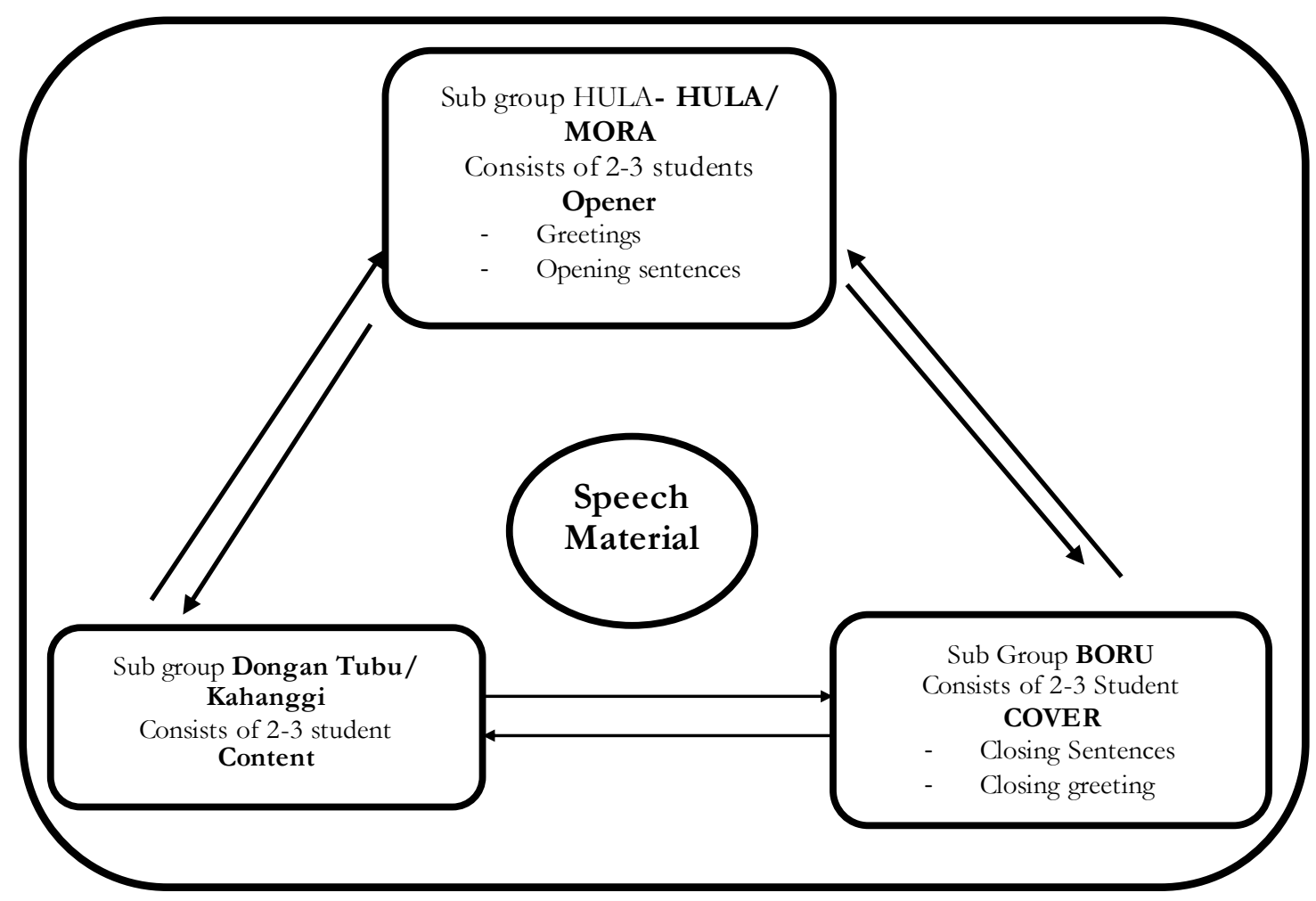

Figure 1. Learning Media Usage Step in Student Learning Group

In the learning process, students are divided into 5 groups of clans consisting of 5-6 students each group. Because the majority of students come from the Batak South Tapanuli. The clan is a clan derived from Tapsel such as Group 1: Hasibuan family, Group 2: Siregar Family, Group 3: Dalimunthe Family, Group 4: Rambe family, and Group 5: Harahap family. Each of the family consists of Mora/Hula-Hula, Kahanggi/Dongan Tubu, and Boru.

This Visual Media is like a concept map in speech learning where, students can understand ways of drafting speeches by looking at the kinship of Dalihan $\mathrm{Na}$ Tolu. The way of stacking is also in a family-level manner, where the duties and functions of each household are different to complete/compose a good speech according to the elements in the speech. So this media is what will bring students to be on the road, way and understand the writing of good speech according to the purpose of the speech.

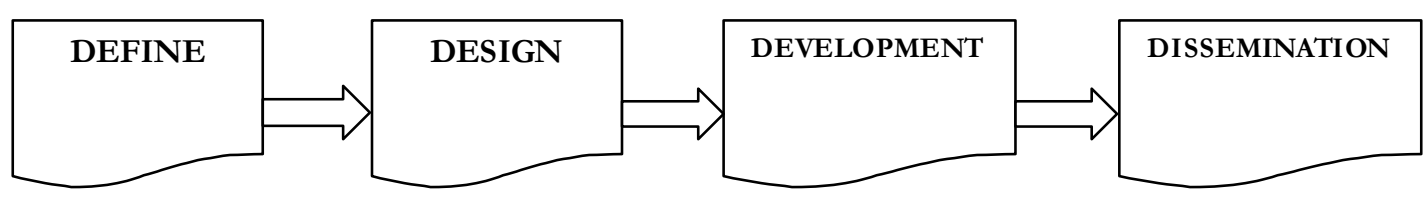

Figure 2. Steps to Research and Development According to Thiagarajan (1974)

Based on the images can be explained among others Define (definition) is an activity to determine what products to be developed, along with the specifications. This stage is an analysis of the needs conducted through research and literature study. The design is to contain activities to make designs on products that have been defined. The development is an activity that makes the draft into a product and tests the validity of the product repeatedly until the product is produced according to the specifications set. Dissemination (dissemination) is the activity of disseminating products that have been tested to be exploited by others. 


\section{Discussion}

Testing of the product is conducted in a number of steps and revisions made by four stages, namely: (1) material expert validation, (2) Validation of learning design experts, (3) Validation of Learning Media experts, (4) field trials. These stages are accompanied by revision of the product. Revisions were made based on the validation and the results of the field trials, therefore the media of the Batak-cultural visual learning has a valid status.

Validation is done with the product for the purpose of knowing the opinion of the material experts, learning design experts, and media experts on the accuracy of the design, aspects of learning and correctness of content, and learning design.

\subsection{The Feasibility of Visual Learning Media Characteristic of Batak Culture "Dalihan Na Tolu”}

Before conducting field trials, researchers validated the media from 3 members consisting of material experts, experts, and learning media experts. The result of the validation from severe experts demonstrates that the media of the culture of visual learning Batak "Dalihan $\mathrm{Na}$ Tolu" is worth using. Here's the result:

Table 1. Validation Results of Visual Learning Media Characteristic of Batak culture

"Dalihan Na Tolu" by Experts

\begin{tabular}{|l|l|l|l|}
\hline No & Experts & Average Rating & Criteria \\
\hline 1 & Material experts & $96,87 \%$ & Excellent \\
\hline 2 & Design expert & $96,87 \%$ & Excellent \\
\hline 3 & Media experts & $95 \%$ & Excellent \\
\hline
\end{tabular}

In the table of percentage of media validation results of the culture of visual learning Batak Dalihan Na Tolu deserves to be used as a learning medium for students of Grade VI Elementary School. As for the media experts to give a value of $95 \%$, learning design experts with a percentage of $96.87 \%$ and material experts with a percentage of $96.87 \%$. The total percentage of the experts with a percentage of $96.24 \%$, which can be concluded that the culture of visual learning of Batak Dalihan $\mathrm{Na}$ Tolu is decent and can be used in field trials, although it initially requires revision in some Front. The percentage of media feasibility that is validly validated by an expert can be seen on the following figure 3:

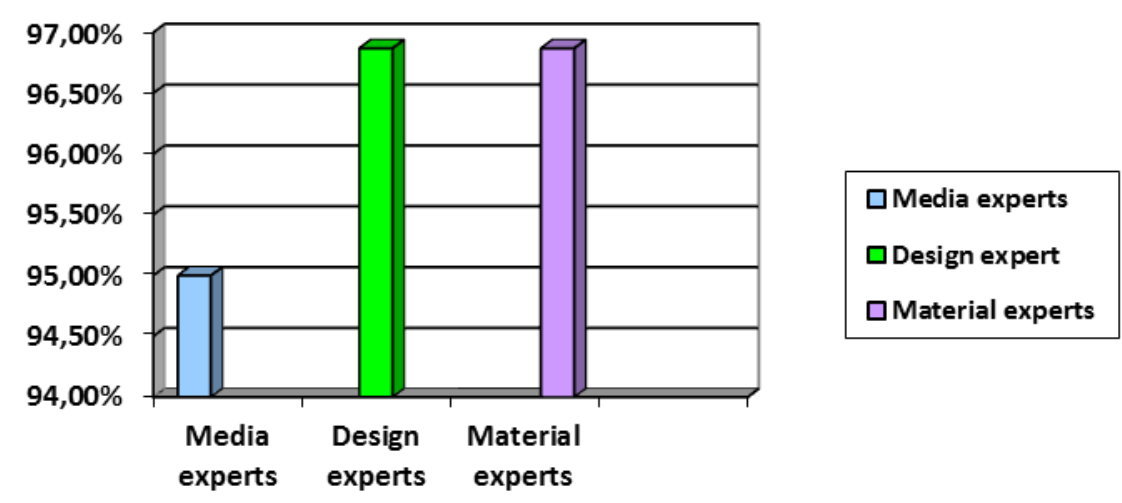

Figure 3. Percentage Validation Results

It can be concluded that the Visual Learning Media Characteristic of Batak culture "Daliban Na Tolu" is very good and worth testing. 


\subsection{The Effectiveness of Visual Learning Media Characteristic of Batak Culture "Dalihan Na Tolu"}

\section{a. Small Group field Trial Results}

The study also refers to student learning outcomes consisting of pretests and Postest grades. The study was conducted in 2 groups consisting of 10 students from small groups and 30 students from big groups.

Table 2. Learning Outcomes by Using the Visual Learning Media Characteristic of Batak Culture "Daliban Na Tolu" in Small Group Trials

\begin{tabular}{|c|c|c|c|c|c|c|c|}
\hline \multirow[b]{2}{*}{$\begin{array}{c}\text { Value } \\
(\mathbf{x})\end{array}$} & \multicolumn{3}{|c|}{ Pretest } & \multirow[b]{2}{*}{$\begin{array}{l}\text { Value } \\
(\mathrm{x})\end{array}$} & \multicolumn{3}{|c|}{ Postest } \\
\hline & $\begin{array}{l}\text { Frequency } \\
\text { (f) }\end{array}$ & (x.f) & Percentage & & $\begin{array}{l}\text { Frequency } \\
\text { (f) }\end{array}$ & ( x.f) & Percentage \\
\hline 10 & 1 & 10 & 10 & 85 & 1 & 85 & 10 \\
\hline 15 & 2 & 30 & 20 & 90 & 7 & 630 & 70 \\
\hline 20 & 3 & 60 & 30 & 95 & 2 & 190 & 20 \\
\hline 30 & 3 & 90 & 30 & - & - & - & - \\
\hline 40 & 1 & 40 & 10 & - & - & - & - \\
\hline Jlh & 10 & 230 & 100 & - & 10 & 905 & 100 \\
\hline Average & \multicolumn{2}{|l|}{23} & - & - & \multicolumn{2}{|l|}{90.5} & - \\
\hline
\end{tabular}

According to table 2, the data was obtained before using the Batak Dalihan Na Tolu Cultural Visual Learning media and the changes in small group tests with an average value of 23, with the criterion "less" meaning the value Students need to be upgraded again. As for the student's learning after using the Batak Daliban $\mathrm{Na}$ Tolu Cultural Visual Learning media and its changes in the small group test with an average value of 90.5, with "excellent" criteria. It can be said that the use of Batak Dalihan $\mathrm{Na}$ Tolu's cultural-visual learning media is a very significant improvement. So the learning outcomes can be classified into the following graphs:

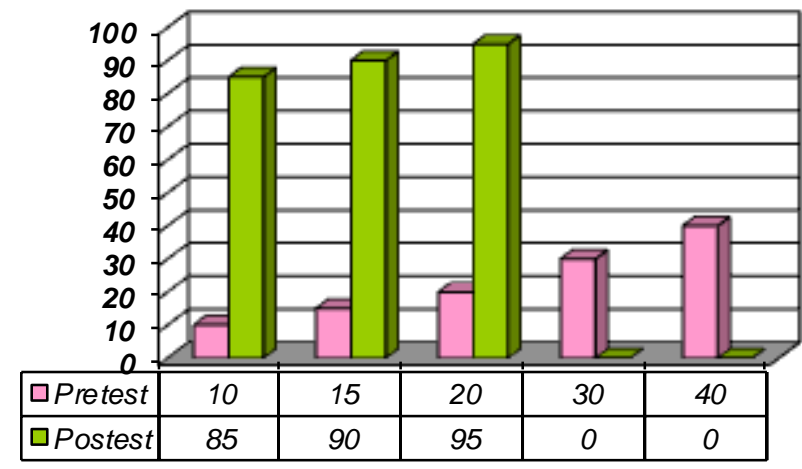

Figure 4. Small Group Learning Results

The Visual Learning Media Characteristic of Batak culture "Daliban Na Tolu” for small groups can be counted using gain score

$$
\begin{aligned}
& (\mathrm{g})=\frac{(\text { gain })}{(\text { gain)max }}=\frac{\text { Postest })-(\text { pretest })}{100-(\text { pretest })} \\
& g=\frac{90.5-23}{100-23} \\
& g=\frac{67.5}{77} \\
& g=0,87
\end{aligned}
$$


Based on the results of the test, the increase in the results of the student learning test was used in the visual learning media with Batak culture "Dalihan Na Tolu" and its changes from the small group trial of 0.87 in the Range $g \geq 0.7$ which can be deduced in the category "High".

\section{b. Big Group field Trial results}

After conducting a field trial of small groups and escalation occurred. The researchers conducted a field trial of 30 students in big groups. The results of the trial in big groups were conducted with the learning process before and after using a visual learning media with Batak Dalihan $\mathrm{Na}$ Tolu in Indonesian language content. Here are the student learning outcomes in the following table 3 :

Table 3. Learning Outcomes by Using the Visual Learning Media Characteristic of Batak Culture "Dalihan Na Tolu" in the Big Group Trials

\begin{tabular}{|c|c|c|c|c|c|c|c|}
\hline \multirow{2}{*}{$\begin{array}{l}\text { Value } \\
(\mathrm{x})\end{array}$} & \multicolumn{3}{|c|}{ Pretest } & \multirow{2}{*}{$\begin{array}{l}\text { Value } \\
\text { (x) }\end{array}$} & \multicolumn{3}{|c|}{ Postest } \\
\hline & $\begin{array}{c}\text { Frequency } \\
\text { (f) }\end{array}$ & (x.f ) & Percentage & & $\begin{array}{c}\text { Frequency } \\
\text { (f) }\end{array}$ & ( x.f ) & Percentage \\
\hline 20 & 5 & 100 & 16,66 & 80 & 4 & 320 & 13,33 \\
\hline 25 & 4 & 100 & 13,33 & 85 & 6 & 510 & 20 \\
\hline 30 & 4 & 120 & 13,33 & 90 & 10 & 900 & 33,33 \\
\hline 35 & 2 & 70 & 6,66 & 95 & 8 & 760 & 26,66 \\
\hline 40 & 3 & 120 & 10 & 100 & 2 & 200 & 6,66 \\
\hline 45 & 10 & 450 & 33,33 & - & - & - & - \\
\hline 50 & 1 & 50 & 3,33 & - & - & - & - \\
\hline 55 & 1 & 55 & 3,33 & - & - & - & - \\
\hline Jlh & 30 & 1065 & 100 & - & 30 & 2690 & 100 \\
\hline Average & \multicolumn{2}{|c|}{35,50} & - & - & \multicolumn{2}{|c|}{89,66} & - \\
\hline
\end{tabular}

According to table 3, you can get learning results before using a visual learning media characterized by Batak Dalihan $\mathrm{Na}$ Tolu by obtaining an average value of 35.50 with the criteria "less" which means the improvement of learning in Big groups. While the results of learning gained after using the culture of visual learning Batak Dalihan $\mathrm{Na}$ Tolu achieved an average value of 89.66 with "excellent" criteria in big groups. It was concluded that there was an increase in the big group field trials which were excellent and can be shown on the following figure 5:

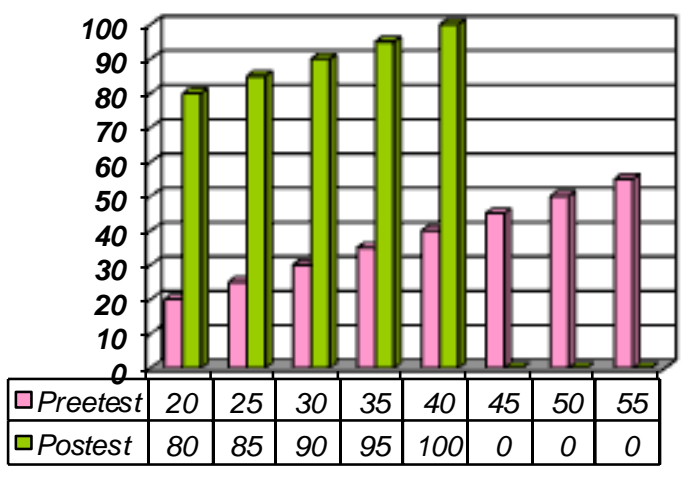

Figure 5. Big Group Learning Results 
The Visual Learning Media Characteristic of Batak culture "Dalihan Na Tolu” for big groups can be counted using gain score

$$
\begin{aligned}
& \mathrm{g}=\frac{(\text { gain })}{(\text { gain)max }}=\frac{\text { Postest })-(\text { pretest })}{100-(\text { pretest })} \\
& g=\frac{89,66-35,50}{100-35,50} \\
& g=\frac{54,16}{64,50} \\
& g=0,83
\end{aligned}
$$

Based on the results of the test, the increase in the results of the student learning test is using a visual learning media with Batak culture "Dalihan $\mathrm{Na}$ Tolu" and its changes from the trial of the big group of 0.83 increase in the Range $g \geq 0.7$ which can be deduced in the category "High".

Table 4. Learning Results Small Group and Big Group

\begin{tabular}{|l|l|l|l|l|l|}
\hline No & \multicolumn{1}{|c|}{ Groups } & Pretest & Postest & \multicolumn{1}{|c|}{ gain } & Category \\
\hline 1 & Small Group & 23 & 90,5 & 0,87 & High \\
\hline 2 & Big Group & 35,50 & 89,66 & 0,83 & High \\
\hline
\end{tabular}

Can be deduced student learning results in small groups with a gain value of 0.87 with the category "High" and in big groups with a gain value of 0.83 with the category "High".

\section{c. Student Response Results on Learning Media}

Field trials are done at SDN 11 in the South region of Labuhanbatu district. This trial was conducted on 40 class VI students consisting of 2 groups of 10 students and a big group of 30 students. The purpose of this response poll is to see students ' interest in the use of Batak cultural visual learning Media in relation to the learning process of students in the classroom. The results of the test for visual learning media with Batak culture that applied to class VI at SDN 11 Rantau Selatan as follows:

Table 5. Student Response Outcomes for Batak Dalihan Na Tolu's Cultural Visual Learning Media

\begin{tabular}{|c|c|c|c|c|}
\hline No & $\begin{array}{c}\text { Aspect } \\
\text { Assessment }\end{array}$ & $\begin{array}{c}\text { Number } \\
\text { of Score }\end{array}$ & Average score & Criteria \\
\hline 1 & Content & 198 & $95,19 \%$ & Excellent \\
\hline 2 & Display & 205 & $98,55 \%$ & Excellent \\
\hline 3 & Serving & 172 & $82,69 \%$ & Excellent \\
\hline 4 & Design & 160 & $76,92 \%$ & Good \\
\hline \multicolumn{2}{|l}{ Average number } & 736 & $88,70 \%$ & Excellent \\
\hline
\end{tabular}

From the student response results can be concluded that the media of Batak culture characterized by the "very good" criteria to be developed according to the student response poll with an average of $88.70 \%$. The percentage result collected based on the content assessment aspect, display, presentation and design are developed, among others, content of $95.19 \%$ with excellent criteria, the display of $98.55 \%$ with excellent criteria, presentation $82.69 \%$ with Very good criteria and design amounted to $88.70 \%$ with good criteria. 


\section{Conclusion}

Based on the formulation, objectives, results, and discussion of research on the development of the culture of visual learning of Batak "Daliban $\mathrm{Na}$ Tolu" presented earlier, it can be concluded as follows: 1) The feasibility of using Batak-cultural visual media based on the results of the validation of the material members, design experts and learning media experts shows that the overall average is categorized as "good" and deserves to be used as a learning medium Used in class VI SD. 2) The effectiveness of the use of visual learning media with Batak culture, from the results of the trials that have been done can be concluded that there are differences in pretests results that have not been influenced by learning using media and postes that have been given Influence with learning using the media. In small group trials the application of learning media had an average of N-Gain 0.87 with high criteria. While the big group test has an average of N-Gain 0.83 with high criteria, it is based on the conclusion that the media characterized by Batak culture "Dalihan Na Tolu" can be used to study the theme of leadership.

\section{References}

Arikunto. (2002). Prosedur Penelitian Suatu Pendekatan Praktek. Jakarta : Rineka Cipta Arsyad, A. (2004). Media Pembelajaran. Jakarta: PT Raja Grafindo Persada

Borg, W.R \& Gall, M.D. Gall. (2003). Educational Research: An Introduction. Seventh Edition

Daryanto. (2017). Media Pembelajaran. Bandung: PT. Sarana Tutorian Nurani Sejahtera

Departeman Pendidikan Nasional. (2003). Undang-undang Nomor 20 Tabun 2003 Tentang Sistem Pendidikan Nasional. Jakarta : Depdiknas

Gultom, Dj. Raja Marpodang. (1992). Dalihan Na Tolunilai budaya suku Batak. Medan: CV. Armanda.

Ghufron, A. (2017). Pengembangan Pembelajaran Berbasis Nilai-Nilai Budaya Yogyakarta Di Sekolah Dasar. Cakrawala Pendidikan. XXXVI. No.2.

Hadi, W. (2018). Development of interactive Media on Learning Explanatory Text for Students of Eleventh Grade Junior High School Leeutenant General Haryono M.T. Education and Humanities Research, Vol 200.

Prasasti, T.I., Solin, M., and Hadi, W. (2020). The Effectiveness of Learning Media Folklore Text of North Sumatera Based on Blended Learning by 10th Grade Students of Vocational High SchoolHarapan Mekar-1 Medan. Budapest International Research and Critics in Linguistics and Education (BirLE) Journal Vol 2 (4): 480-490.

Sinaga, B. (2009). Model Pembelajaran bermuatan Soft Skill dengan Pola Interaksi Sosial Daliban Na Tolu”. Generasi Kampus. Vol 2, No.1.

Sugiyono. (2015). Metode Penelitian Pendidikan, (Pendekatan Kuantitatif, Kualitatif, dan R\&D ). Bandung: Alfabeta.

Sadiman, A. (2009). Media Pendidikan. Jakarta: PT Raja Grafindo Persada

Saragi, D. (2008). The Development of Learning Media Based on Mind Map in Exposition Text. Education and Humanities Research, Vol 200.

Suyono \& Hariyanto. (2017). Belajar dan Pembelajaran. Bandung: PT Remaja Rosdakarya

Syakur, A., et. Al. (2020). Developing English for Specific Purposes (ESP) Textbook for Pharmacy Students Using On-Line Learning in Higher Education. Britain International of Linguistics, Arts andEduca tion(BIoLAE) Journal Vol.2 (1): 467-474.

Syakur, A., Sugirin, and Widiarni. (2020). The Effectiveness of English Learning Media through Google Classroom in Higher Education. Britain International of Linguistics, Arts and Education (BIoLAE) Journal Vol.2 (1): 475-483. 